\title{
DO LEADERSHIP STYLE AND ORGANIZATIONAL COMMUNICATION INCREASE TO ORGANIZATIONAL COMMITMENT? STUDY AMONG HOSPITAL STAFF
}

Rahmi WIDYANTI ${ }^{1 *}$

BASUKI ${ }^{2}$

SUSILADEWI ${ }^{3}$

Received: Aprilie 2019 | Accepted: July 2020 | Published: August 2020

Please cite this paper as: Widyanti, R. et. al. (2020). Do leadership style and organizational communication increase to organizational commitment? Study among hospital staff, Holistica Journal of Business and Public Administration, vol. 11, iss. 2, pp. 17-24

\begin{abstract}
General problems who experienced by some large hospitals in Indonesia weakness caused by factors other than internal (internal weakness), especially of facilities and human resources who is still relatively less and still the weak competitiveness of organization (low competitive advantage) and combined with the terrier such as qualities and support of leadership. The weak in the field of organizational communication on hospital in anticipation regional and international free market competition. The gap medical staff functional (MSF), between in government hospital and private hospital has resulted in the role of an assignment with the condition a very complicated. Specialized doctors tend to be part time in government hospital, place official work. The problems need to examined the more distant is how to create commitment staff functional medical and so far, of needed harmonious relations. Organizational communication to create cooperation and a good relationship and pattern leadership in managing the hospital to medical staff functional and nonmedical is a thing also become the adhesive for the hospital system that could increase commitment. This study aims to assess empirical pertaining to with a variable in leadership styles and organizational communication impact they may have on organizational commitment of MSF. A method of survey was used in this study, while the kind of research is considered to be explanatory research. Such data was gathered through 43 MSF and analyzed using Partial Least Square (PLS). This research result show that variable of leadership styles could to increase an organizational communication. Leadership styles significant and could influence on organizational commitment, and organizational communication the influence on organizational commitment as significant.
\end{abstract}

Keywords: Leadership styles, communication, commitment, hospital

JEL Classification: D23; L20; L26; O15

\footnotetext{
${ }^{1}$ Islamic University of Kalimantan, Banjarmasin, Indonesia, rahmibasuki@gmail.com

${ }^{2}$ Islamic University of Kalimantan, Banjarmasin, Indonesia, msibasukidr@gmail.com

${ }^{3}$ Islamic University of Kalimantan, Banjarmasin, Indonesia, Susiladewi@gmail.com

*Corresponding author
} 


\section{Introduction}

Successful an organization in achieving its intended purpose depends on members of an organizational commitment. Organizational commitment is a sense of confidence and values of share with someone so far part in organization (Meyer and Allen, 1990).

The hospital government as well as private not much different from other organizations, needed good and right in management. Public problems experienced by some large hospital in Indonesia weakness caused by factors other than internal (internal weakness), especially that means by which is still relatively less and still the weak competitiveness of organization (low competitive advantage) and less prepared to feedback as well as the leadership and organizational communication the hospital in anticipate regional and international free market competition (Widajat, 2009).

Human resources in a hospital consisting of medical staff and non-medic. Medical staff that is medical staff functional (MSF) is a group of specialists and a dentists and nurses with their of expertise. The gap medical staff functional (MSF), between in government hospital and private has resulted in the role of duties and obligations especially doctors specialist with the condition a very complicated. Specialized doctors tend to be part time in government hospital, place official work (Trisnantorto, 2006).

The problems need to examined more in depth is how to create commitment medical staff functional and non medical, needed harmonious relations. In the hospital commitment very important as a link system that has been created by management hospital. Organizational communication to create cooperation and a good relationship and leadership style in managing the hospital to the medical staff and non medical is a thing also become the adhesive for the hospital system that can grow commitment.

Mathieu and Zajac (1990), Nowack (2006), Robbin (2008) are stated that the commitment effected by leadership style. Model Full range leadership (Full Range Leadership Model) developed by Bass $(1990,1999)$ it is stated that 3 leadership style, that is transformational, transactional, and passive/avoidant.

In addition, the process of good communication can give something positive in to step up their commitment employees to organizations, but can also on the other hand. Organizational communication is exchange information between the two or more individuals or group in an organization who created the common basis understanding and feelings (Phillips and Gully, 2012). Whereas Dessler (2005) it is stated organizational communication is the exchange of information and transmission of the meaning in between a couple of an individual or groups all over part of an organization. Cascio (2006) explain, where is one of the aspects that influence in to step up their commitment tens of thousands of worker to organizations is communications in a central organization. On the economic of every organizational process there is a relation such that it of ownership 
needs to be embraced by the majority. Any such process to have a truly functional with a system of communication between a good way (Ince and Gul, 2011).

Thoroughly theoretical and empirical research showed that connecting between variables leadership styles against commitment (Mathieu and Zajac, 1990; Nowack. 2006; Shirbagi, 2007). This organizational communication against commitment (Philips and.Gully, 2012; Cascio, 2006, Ince and Gul, 2011), but have not been integrated of all the variables is. In this research, developed a model that is integrated in all the variables leadership style and organizational communication impact they may have on the organizational commitment of employees.

\section{Literature Review}

Sharon Clinebell, et al., (2013) has been carrying out a study with a title "Impact of Leadership style on employee organizational commitment". Variable reaches as high as the leadership disclosed in the research handed over to people consisting of the style of transformational leadership that we are doing, transactional and leadership style and passive/avoidant. The research result show that the leadership style that we are doing transformational and transactional in a positive way in also had an impact significantly correlates with organizational commitment, while a leadership style that we are doing the passive/avoidant in a negative way affect significant organizational commitment.

Magdalene Suliyem (2016), have do research by the title "The influence of organizational communication and job satisfaction on organizational commitment". Based on examining hypothesis research suggests that is the direct positive communication a labour organization to organizational commitment. This giving purpose organizational communication directly influence to organizational commitment.

R.Wayne Pace (2002) has been carrying out a study with a title "Organizational dynamism unleasing power in the workforce, London quorum books. The result of states that there have been communication to have an influence what is important, may in fact become a affect tens of thousands of worker be deeply dissatisfied and leave the organization PT PGN promised to supply the organizational commitment they tended to levels of education show decreasing. So a communication that their respective authorities should encourage positive commitment on the part of someone over organization.

Most villagers still believe a process by which individual so they can be affecting the group that they must reach a common purpose (Northouse, 1997). The study on theory of leadership that we are doing of all time ranking of family welfare started despite the rapid expansion of the theory of the nature (trait theory), a group and exchange of a private economic analyst said (group exchanges theories), contingency theory. The theory of the trunk line and the purpose of (path goal leadership theory). The theory of leadership that we are doing charismatic (charismatic leadership theory, the theory of leadership that we 
are doing (transformational leadership theory). Leadership theory that we are doing (transformational leadership theory), (Luthan, 2006; Goleman, 2000), explain a leadership style that we are doing manager of there are six areas of PT. PGN promised to supply: (1) coercive style, (2) authoritative style, (3) affiliative style, (4) democratic style, (5) pacesetting style, and (6) coaching style.

Full range leadership model developed by Bass $(1990,1999)$ mentioned that there are 3 leadership style, namely transformational, transactional, and the passive/avoidant. This research using the theory full range leadership model put forward by Bass in clarifying understanding types of leadership style, as of theories is able to describes the phenomena of leadership happens on the field.

Organizational communication is exchange information between two or more individuals or group in an organization who created the common basis understanding and feelings (Philips and Gully, 2012) while, Dessler (2007) said that communication organization is exchange information and transmission of meaning among some individual or groups all over part of an organization.

Cichy, Cha and Kim (2009) transport and communications have stated how an organizational commitment as the engagement properties of an individual person with an organization that makes it possible for a man of a certain high commitment to champion loving care for a strong desire for still members of an organization it to relevant national authorities, the willingness of marry shall restrain work foremost in the interest of trying the best can in the best possible conditions as they are called in confidence in the Indonesian economy, and decline in revenue as strong against values and organizational goals. Are more distant to might explain (Loethan, 2006; Robbin, 2006; Mathis and Jackson, 2006; Suri, 2007; Cohen, 2007) organizational commitment adjusted according to all my characters were covering: age, status, length of service and is holding a match point at has struggles to help the organization whose height is an employee who is more stable and more productive so that might also it is even profitable for organization.

Meyer and Allen (1991) and Curivan (2004) explained that 3 aspect organizational commitment. First, commitment affective consist of: personal characteristic, office characteristic, work experiences and structural characteristic. Second, continuous commitment consisting of magnitude and/or the level of investment of individual or wager a side, and perception over lack of work alternatives. Third, normative commitment consisting of experience individual before entering into organization (experience in family socialization culture and experience socialization during their stay in the organizations.

$\mathrm{H} 1$ : The influence leadership style to organizational communication in hospital

$\mathrm{H} 2$ : The influence leadership style to organizational commitment in hospital

H3: The influence organizational communication to organizational commitment in hospital 
Figure 1. Conceptual Framework

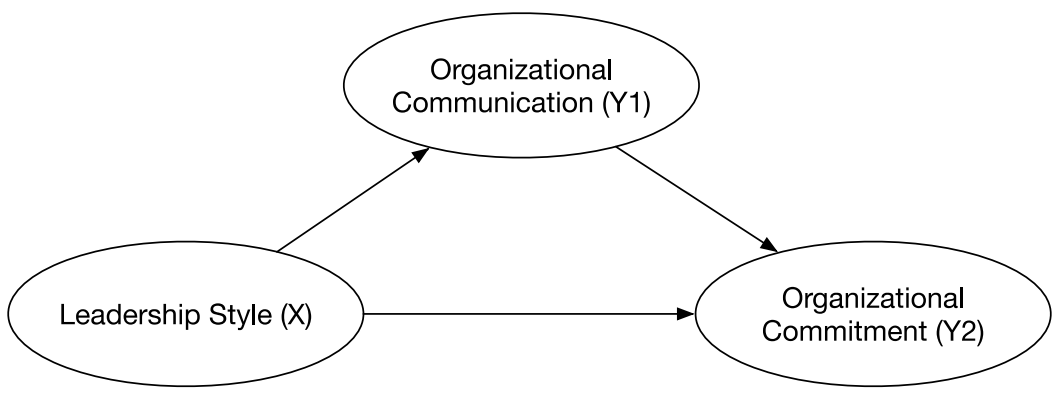

Source: Widyanti, R., 2019

\section{Research Method}

The objective population of this investigation is 43 (forty-three) Medical Staff Functional (MSF) with a survey method. The information was gathered through surveys during the time of June 2018 until January 2019. By utilizing the Partial Least Square (PLS), the standard principle is that the base number of perception is in any event fivefold the number of perceptions (Hair et al., 2010). The relationship among builds is delineated in a hypothetical structure. The five-point Likert-type scales (1 - strongly disagree; 5 strongly agree) were applied all through the survey.

\section{Results and Discussion}

Based on the research result obtained data on the age of the majority of respondents between $44-49$ years (56.78\%), genders of respondent are a man (74 \%) with working period of the old time 11-14 years (46.22\%) has become MSF at the hospital. Weighted the answer of respondent said that could not agree to a style leadership with a score of 4.84 transformational. Respondent said very agree with a communication that delivered directly with the score 4.64 and declared could not agree how a commitment based on the experience work somewhere else can form organizational commitment for the better by the score 4.84. The testing of hypotheses done with t-test lane in the extend of the full direct effect. The result of the analysis in a complete manner, the result of the analysis contained in Partial Least Square (PLS).

Table 1 The Result of testing Hypotheses

\begin{tabular}{lcccc}
\hline \multicolumn{1}{c}{ Independent Variable } & Dependent Variable & $\begin{array}{c}\text { Path } \\
\text { Coefficient }\end{array}$ & p-value & Remark \\
\hline $\mathrm{X} 1$ = Leadership Style & $\mathrm{Y} 1=\begin{array}{c}\text { Organizational } \\
\text { Communication }\end{array}$ & 0.413 & $<0.001$ & Significant \\
\hline $\mathrm{X} 1$ = Leadership Style & $\mathrm{Y} 2=\begin{array}{c}\text { Organizational } \\
\text { Commitment }\end{array}$ & 0.346 & $<0.001$ & Significant \\
\hline $\begin{array}{c}\text { Y1 = Organizational } \\
\text { Communication }\end{array}$ & $\begin{array}{c}\text { Y2 = Organizational } \\
\text { Commitment }\end{array}$ & 0.560 & $<0.001$ & Significant \\
\hline
\end{tabular}

Source: primary data, produce (2018) 
HOLISTICA Vol 11, Issue 2, 2020, pp. 17-24

This result has shown if communication and transformational leadership going good as to be better to commitment organizational of medical staff functional (MSF).

The results of testing hypotheses the direct paths effect can be seen in figure diagram the following:

Figure 2. Path diagram of direct analysis

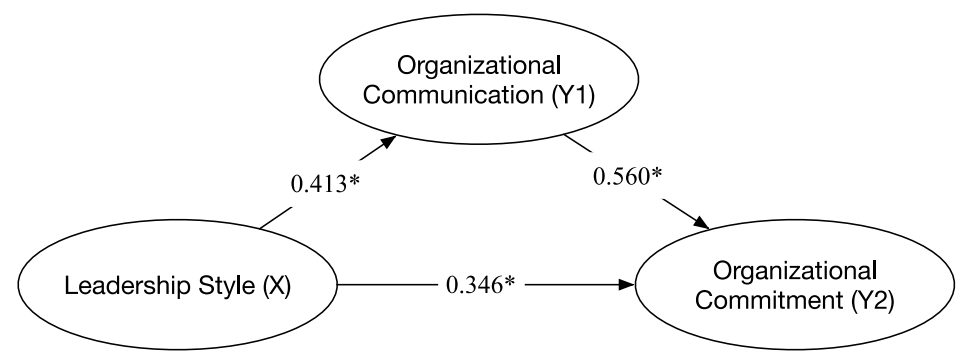

Source: Widyanti, R., 2019

Based on the results of the testing hypotheses is statistically in Table 1 and Figure 2, these charges in the future as follows:

1. The Leadership Style (X1) had an impact significantly correlates with his best work inside the organizational communication (Y1). The result of the analysis using a PLS obtained of the coefficient of direct impact as much as 0.413 in $p$-value $>0.001$, that is significant.The remembrance of the coefficients of lines of railroad for grades although very close is positive, can be defined that the lower the good a leadership style that we are doing that was felt by SMF, which then of the communication risen by the end of organization.

2. Leadership styles (X1) that we are doing has significant impact on organizational commitment (Y2). The result of the analysis using a PLS obtained of the coefficient of a nation lines as much as 0.346 with $p$-value $=0.001$, that's mean significant. This can be are defined that it is well put his worries behind him of leadership styles (X1) that we are doing has been affective commitment on the part of organizational commitment(Y2).

3. Organizational communication (Y1) also had an impact significantly correlates with organizational commitment (Y2). The result of the analysis using a PLS obtained of the coefficient of a nation lines of as much as $0.560>p$-value.

This result has shown leadership style and organizational communication could be increasing organizational commitment. This founded accordance to Bass (1994) and Philip J. (2012)

\section{Conclusion}

In spite of the fact theory of style leadership and organizational communication and organizational commitment are validated within the medical functional staff, the 
HOLISTICA Vol 11, Issue 2, 2020, pp. 17-24

implementation of the public hospitals is not as easy as arranged. This research examines the leadership styles and organizational communication and its relation to organizational commitment among the hospital staff. The research shows that all of the proposed hypothesis shows a significant effect. However, the most influential effect on organizational commitment was mostly reflected by an organizational commitment by the superordinate in hospital organization rather than the leadership style.

\section{References}

Allen, N.J., Mayer, J.P. 1990. The Mesurement and Antecedents of Affective, Continuance and Normative Commitment to The Organization. Jurnal of Occupational Psycology, 63, 1-18

Allen, N.J., Mayer, J.P. 1996. Affective, Continuance and Normative Commitment to The Organization: an Examination of Contruct Validity.. Jurnal of Occupational Psycology, 49, 252276

Bass, B.M. (1985). Leadership and Performance beyond Expectation. New York: The Free Press.

Bass, B. M. (1990). From transactional to transformational leadership: Learning to share the vision. Organizational Dynamics, 18(3), 19-31.

Bass, B.M., Avolio, B.J. (1994). Improving Organizational Effectiveness through Transformational Leadership. Newbury Park, CA: Sage.

Cascio, W.F. 2006, Managing Human Resource: Prtoductivity, Quality of Work Life, Profit, Edisi Ke7 USA. McGraw_Hill, Commpenies,Inc.

Cohen, Aaron, 2007, Commitment $n$ Evaluation and Reconceptualization of Organizational, Human Resource Management Review, Vol. 17,pp.336-354.

Cchy, F. Ronald, Cha JaeMin dan KimSeungHyun, 2009, The Relationship Between Organizational Comitment and Contextual Performance among Private Club Leader, Juornal of Hospitality Management, Vol.28,pp.53-62.

Clinebell, dkk. (2013). The impact of leadership style on employee organization commitment. Journal of Service Science.

Dessler, Gary. 2000. Managing Organizations: in an Era of Change. USA: Harcourt Brace \& Company.

Dessler,Gary. 2005. Management: Leading People and Organizations in the 21st Century. USA: Prentice Hall.

Dale, Timpe. 2008 Leadership. Seri Manajemen Sumber Daya Manusia, Penerbit Elex Media Komputindo Kelompok Gramedia, Jakarta.

Farid, Poniman. Indrawan, Nugroho. Jamil Azzaini. 2008. Kubik Leadership, Penerbit PT. Gramedia, Jakarta.

Ferdinand, A., 2000, Manajemen Pemasaran : Sebuah Pendekatan Stratejik, Research Paper Series, Program Magister Manajemen Universitas Diponegoro, Semarang.

Ferdinand, A., 2003. Sustainable Competitive Advantage : Sebuah Eksplorasi Model konseptual. Fakultas Ekonomi Universitas Diponegoro. Semarang

Ferdinand, A., 2005. Structural Equation Modelling Dalam Penelitian Manajemen. Seri Pustaka Kunci No.06 Program Magister Manajemen Universitas Diponegoro.

Ferdinand, A., 2006. Metode Penelitian Manajemen. Badan Penerbit Universitas Diponegoro, Semarang.

Goleman, Daniel. 2000. Leadership That Gets Result, Harved Bussiness Review, USA, March-April. Greeberg, Jerald dan Brono A. Robert, 2011, Behavior in Organization, 10b Edition, Person Education, USA, Ebook Online, htt://www.goodreads.com 
HOLISTICA Vol 11, Issue 2, 2020, pp. 17-24

Ince, Mehmet, and Gul, Hasan, 2011, The Rol of The Organizational Communication on Employees' Perception of Justice; A Sample of Public Instution from Turky. Eroupean Journal of Social Science. Vol. 21, No. 1

Luthans, Fred. 2006. Perilaku Organisasi Edisi 10, Yogjakarta.

Magdalena, Suliyem 2016, Pengaruh Komunikasi Organisasi dan Kepuasan Kerja Terhadap Komitment Organisasi.

Mathieu, J.E. and Zajac, D.M. 1990. A review and meta-analysis of the antecedents, correlates, and consequences of organizational commitment. Psychological Bulletin. Vol. 108. pp. 171-94.

Mathis, I. Robert dan Jacson, H. John, 2006, Human Resource Management. Ninth Edition, South Western, College, Publishing, USA.

Mayer, J.P and Allen. 1991. A Three-Component Conceptualizition Of Organization Commintment. Human Resource Management Review, Vo. 1 P.61-89.

Northouse, Peter.G. 1997. Leadership Theory and Practice. London: Sage Publication.

Nowack, Kenneth. 2006. Does Leadership Practices Affect a Psychologically Healthy Workplace? Working Paper. Consulting Tools Inc

Pace, R. Wayne, 2002, Organizational Dynammism Unleashing Power in The Workforce. London: Quorum Books.

Phillips, Jean M., Gully, Stanley M. 2008. Organizational Behavior Tools for Success.USA: South Western Cengage Learning.

Robbin, Stephen, 2006, Perilaku Organisasi, Konsep, Kontraversi, Aplikasi, Jilid 1, Edisi Bahasa Indonesia, Prenhallindo, Jakarta.

Robbins, Stephen, P. and Judge, Timothy, A. 2008. Perilaku Organisasi. Buku 1 dan 2. Terjemahan: Diana Angelica. Jakarta: Penerbit Salemba Empat.

Suri, R.K, 2007, Encyclopedia of Organizational Behavior, McGraw Hill, New York.

Shirbagi, Naser. 2007. Exploring Organizational Commitment and Leadership Frames within Indian and Iranian Higher Education Institutions. Bulletin of Education \& Research. Vol. 29, No. 1, pp. 17-32.

Solimun, 2005, Metodologi Penelitian Kuantitatif, Program Pascasarjana Universitas Brawijaya

Solimun 2010 Permodelan Persamaan Struktural Pendekatan PLS,, Program Studi Statistik FMIPA, Program Doktor Ilmu Manajemen FE Universitas Brawijaya

Steer dalamCurrivan, B. Douglas, 2004, The Causal Order of Job Satisfaction and Organizational in Model of Employee Turnover, Human Resource Management Review, Vol.9, No. 4 pp 495524.

Trisnantoro, Laksono. 2006. Memahami Penggunaan Ilmu Ekonomi Dalam Manajemen Rumah Sakit, Gajah Mada University Press, Yogyakarta.

Widaya, Rochmanadji. 2009. Being A Great And Sustainable Hospital: Beberapa Pitfall Manajemen Yang Harus Diwaspadai, PT Gramedia Pustaka Utami, Jakarta.

Widyanti, Rahmi, et al., 2012, The Perception of Individual and Organizational Career in Increasing the Organizational Commitment, Jounal of Economics, Business and Axxountancy, Ventura, Vol. 15, No.2, pp. 231-244

Zafer. (2012). Organizational culture, leadership style and organization commitment in turkish logistics industry. 